\title{
Vegetable and Fruit Consumption Behaviours of Secondary and High School Students
}

\author{
Ortaokul ve Lise Öğrencilerinin Sebze ve Meyve Tüketimi Davranışları \\ Özcan Aygü̈n ${ }^{1}$, Gonca Karayağız Muslu* ${ }^{1}$
}

\begin{abstract}
Introduction: Individuals should consume at least five portions of vegetables and fruit per day to maintain a healthy diet. Therefore, the factors that affect vegetable and fruit consumption among young people and adolescents should be identified, and the causes of inadequate consumption of vegetables and fruit should be examined. The aim of this study was to determine the daily amount of vegetable and fruit consumption of adolescents studying at secondary and high schools, their distribution according to the vegetable and fruit consumption change stages in the transtheoretical model, and the factors related to the change processes. Method: This study used a descriptive research design. It was conducted in 2016 at four secondary schools and three high schools affiliated with the Fethiye District Directorate of National Education. The data were collected from 1,870 students through stratification conducted at each school. An introductory information form, the transtheoretical model vegetable and fruit consumption change stages and change process scales were used to collect the data. Number, percentiles, independent samples t-test and Oneway Analysis of Variance (ANOVA) were used for analysis of the data. Findings: This study found that the participants were aged from 11 to 17. Of the participants, 59.4\% were male, and approximately two thirds of them were secondary school students. According to the change stages of the transtheoretical model, $32.1 \%$ of the students were regularly consuming five portions of vegetables and fruit for more than one month. This study also found that there was a statistically significant difference between the sex, age, grade, number of siblings of the students, the economic status of their families, having the support of their families and friends, their access to vegetables and fruit at home and school, and their daily consumption of vegetables and fruit, as well as their fruit and vegetable consumption behaviors $(\mathrm{p}<.01)$. The change stages of the transtheoretical model and the vegetable-fruit consumption behaviors of the students were found to be related $(\mathrm{p}<.05)$. Conclusion: This study found that the vegetable and fruit consumption of males and adolescents older than 15 years of age was inadequate; factors such as economic status, the influence of family and friends, and access to vegetables and fruit had effects on consumption. The number of portions consumed per day was related to the vegetable and fruit consumption behavior. Considering these results, it is recommended that health improvement practices should be developed, and the support of individuals and institutions should be increased, including the support of family, school, friends, teachers, and health institutions in particular. These health improvement practices should be developed for students who are older, who are in the upper grades, who are male, who suffer from economic insufficiency, and who lack access to vegetables and fruit. Access to vegetables and fruit should be made easier in the areas where these students reside.
\end{abstract}

Key words: adolescent, student, behavior, vegetable and fruit, transtheoretical model

\section{ÖZET}

Giriş: Sağlılı beslenmenin sürdürülebilmesi için günlük sebze ve meyve tüketiminin en az beş porsiyon olması gerekmektedir. Bu nedenle, gençlerde ve ergenlerde sebze ve meyve tüketimini etkileyen faktörlerin belirlenmesi, yetersiz tüketimin nedenlerinin araştırılması gerekmektedir. Bu çalışmanın amacı, ortaokul ve lise düzeyinde öğrenim gören adölesanların günlük sebze ve meyve tüketimi miktarları, transteorik model sebze ve meyve tüketimi değişim aşamalarına göre dağılımları ve değişim süreçleri ile ilişkili faktörlerin belirlenmesidir. Yöntem: Fethiye İlçe Milli Eğitim Müdürlüğüne bağlı dört ortaokul ve üç lisede 2016 yılında yapılan bu çalışma tanımlayıcı tiptedir. Her okuldan tabakalama yapılarak 1870 kişiden veri toplanmıştır. Araştırmanın verilerinin toplanmasında, tanıcı bilgi formu, transteoretik model sebze ve meyve tüketimi değişim aşamaları ve değişim süreci ölçekleri kullanılmıştır. Verilerin analizinde ise, sayı, yüzdelik dilimler, bağımsız değişkenlerde $t$ testi ve Tek Yönlü Varyans Analizi kullanılmıştır. Bulgular: Katılımcıların yaşları 11-17 arasında, \%59.4'ü erkek, yaklaşık 2/3'ü ortaokul öğrencisidir. Transteoretik model değișim aşamalarına göre, bir aydan fazladır düzenli olarak günde beș porsiyon sebze ve meyve tüketen öğrencilerin oranı ise \%32.1'dir. Öğrencilerin cinsiyet, yaş, sınıf, kardeş sayısı, ailelerinin ekonomik durumları, aile ve arkadaş desteğine sahip olmaları, evde ve okulda sebzemeyveye erişim durumları ve günlük tüketim miktarları ile sebze ve meyve tüketim davranışları arasında istatistiksel olarak anlamlı farklılık saptanmıştır $(\mathrm{p}<.01)$. Transteoretik model değişim aşamaları ile sebze-meyve tüketim davranışlarının ilişkili olduğu belirlenmiştir $(\mathrm{p}<.05)$. Sonuç: Çalışma sonucunda, erkeklerin, 15 yaş üzerindeki adölesanların sebze ve meyve tüketimin yetersiz olduğu; ekonomik durum, aile ve arkadaș etkisi, sebze ve meyveye erişim gibi faktörlerin tüketimde etkili olduğu; günlük tüketilen porsiyon sayısının sebze ve meyve tüketim davranışıyla ilişkili olduğu belirlenmiștir. Bu sonuçlar ıșığında, yaşı daha büyük, ileri sınıflarda öğrenim gören, cinsiyeti erkek olan, ekonomik yetersizliği olan öğrencilere yönelik sağlığı geliştirici uygulamalar ve özellikle aile, okul, arkadaş, öğretmen, sağlık kurumları vb. gibi destekleyici bireysel ve kurumsal çevrenin oluşturulması, ögrencilerin bulundukları ortamlarda sebze ve meyveye erişimlerinin kolaylaştırılması önerilmektedir.

Anahtar kelimeler: Adölesan, öğrenci, davranış, sebze ve meyve, transteoretik model

Received / Geliş tarihi: 12.07.2017, Accepted / Kabul tarihi: 16.08.2017

${ }^{1}$ Muğla Sıtkı Koçman Üniversitesi Fethiye Sağlık Bilimleri Fakültesi Hemşirelik Bölümü

*Address for Correspondence / Yazışma Adresi: Gonca Karayağız Muslu, Muğla Sıtkı Koçman Üniversitesi Fethiye Sağlık Bilimleri Fakültesi Hemşirelik Bölümü, Muğla - TÜRKIYE, E-mail: goncamuslu@mu.edu.tr

Aygün Ö, Karayağız GM. Ortaokul ve Lise Öğrencilerinin Sebze ve Meyve Tüketimi Davranışları. TJFMPC, 2017; 11 (4): $245-255$.

DOI: $10.21763 /$ tjfmpc.359809 


\section{GíRIŞ}

Sebze ve meyve tüketimi yeterli ve dengeli beslenmenin önemli bileşenlerindendir. Yapılan çalışmalar günlük beş porsiyon sebze ve meyve tüketiminin kardiyovasküler hastalıkların ve bazı kanser türlerinin görülme sıklığının azalmasında etkili olduğunu göstermektedir. ${ }^{1-2}$ Sebze ve meyvelerdeki lif oranının yüksek olmasının, kan basıncının dengelenmesine, insülin düzenlemesine, açlık hissinin ve kalori alımının azaltılmasına ve dolayısıyla obezitenin önlenmesine katkı sağladığı belirtilmektedir. ${ }^{3}$ Ayrıca, sebze ve meyve tüketimin yetersiz olmasının sonucunda dünyadaki kronik hastalık sıklığının ve buna bağlı ölümlerin artmasına neden olacağı yapılan çalışmalarda ortaya konmuştur. $^{1}$

Bireylere sağlıklı davranışların kazandırılması ve riskli davranışların olumlu yönde değiştirilmesi ve bu değişimin gerçekleştirilmesi için bazı modellerden yararlanılması gerektiği önerilmektedir. ${ }^{4} \mathrm{Bu}$ modellerden biri olan Transteoretik Model (TTM) bireylerin neden ve nasıl değiştiklerini, değişime hazır olma süreçlerini belirlemek için kullanılabilmektedir. ${ }^{5-6} \mathrm{Bu}$ model sigara, alkol ve ilaç bağımlılı̆̆ı gibi riskli davranışların önlenmesinde; güneşten korunma, kilo kontrolü, egzersiz alışkanlığı kazandırma, stres yönetimi gibi pek çok sağlıklı davranışın kazandırılmasında çeşitli araştırmacılar tarafından kullanılmıştır. ${ }^{7}$ TTM sebze ve meyve tüketimini arttırmaya yönelik bazı çalışmalarda da kullanılmıştır. ${ }^{8-11}$

TTM riskli davranışların önlenmesi veya sağlıklı bir davranışın kazandırılması sürecini beş ardışık aşamada değerlendirmektedir. Bu aşamalar bireylerin değişime ne zaman hazır olduklarını, davranışı değiştirmenin sağladığı yarar ve zarar algılarını, davranış değiştirmede kendilerine olan güvenlerini ve davranış değişiminin hangi süreçlerden geçtiğini ortaya koyması açısından hayati önem arz etmektedir. ${ }^{5-6}$ TTM'in başarılı olmasının anahtarı davranış değişikliği sürecinde bireylerin içinde bulundukları değişim aşamalarına özgü girişimlerin planlanmasıdır. Model ayrıca, bireyin davranış değiştirmede kendine olan güvenini yansitan "öz yeterlilik ölçeğil", davranış değişikliğinin artı ve eksilerini ortaya koyan "karar alma ölçeği” ve bireylerin davranışlarını değiştirirken hangi deneyimlerini kullanarak riskli davranışlarını değiştirebileceklerini anlamayı sağlayan "değişim süreci ölçeği” gibi çeşitli ölçüm araçlarını da barındırmaktadır. Bu ölçeklerden biri olan değişim süreci ölçeği, bireyin problemli davranışını anlamasına ve bu davranışa yönelik girişimlerin hazırlanmasına rehberlik etmektedir. ${ }^{5-6}$ TTM'ye göre sebze ve meyve tüketimiyle ilgili davranış değişikliği dönemleri açıklanabilir. Buna göre; gelecek altı ay içinde günde beş porsiyon sebze ve meyve tüketmeyi düşünmeyen ve bunda da herhangi bir sakınca görmeyen bireyler ilk aşama olan düşünmeme aşamasında; gelecek altı ay içinde günde beş porsiyon sebze ve meyve tüketmeyi düşünenler ama henüz eyleme geçmeyenler düşünme aşamasında; gelecek otuz gün içinde günde beş porsiyon sebze ve meyve tüketmeye başlamayı düşünen ve eyleme hazır olanlar hazırlık aşamasında, bir aydan fazla altı aydan daha az süredir günde beş porsiyon sebze ve meyve tüketenler hareket aşamasında ve en az altı aydır günde beş porsiyon sebze ve meyve tüketenler ve bunu sürdürenler son aşama olan devam ettirme aşamasındadırlar. ${ }^{8-11}$ Değişim süreci ölçeği değişimi kolaylaştıran bilişsel ve davranışsal değişkenlerden oluşur. Modelin ilk ve ikinci aşamaları olan düşünmeme ve düşünmede genellikle bilişsel süreçler kullanılmaktadır. Hazırlık, hareket ve devam ettirme aşamalarında ise davranışsal süreçler daha fazla kullanılır. Değişim süreçleri modelin düşünmeme aşamasında çok nadir kullanılmaktadır. Düşünme ve hazırlık aşamalarında ise süreçlerin kullanımlarında artışın olduğu göze çarpar ve hareket aşamasına gelindiğinde değişim süreçlerinin diğer aşamalara göre en yüksek yoğunlukla kullanıldığı görülür. Ancak, bu artış devam ettirme aşamasında azalma eğilimine girebilir. ${ }^{5-6}$ Sebze ve meyve tüketiminde de değişim aşamaları ile değişim süreçlerinin bu ilişkisi benzerlik taşımaktadır. ${ }^{8-11}$

Yapılan çalışmalarda özellikle gençlerde ve adölesanlarda sebze ve meyve alımının günlük tüketilmesi gereken miktardan az olduğu görülmektedir. ${ }^{12-14}$ Türkiye'de yapılan çalışmalarda da sebze ve meyve tüketiminin yetersiz olduğu ortaya konmaktadir. ${ }^{15-16}$

Sağlıklı beslenmenin sürdürülebilmesi için günlük sebze ve meyve tüketiminin en az beş porsiyon olması gerekmektedir ve yaşamın erken dönemlerinde sağlıklı beslenme alışkanlıklarının kazanılması önemlidir. ${ }^{17}$ Adölesan dönem aile ve arkadaş gruplarının etkisi sonucu bireylerin sağlıklı veya riskli davranışlara yatkınlığı olan bir dönemdir ve bu dönemde kazanılan davranışlar genellikle kalıcı olarak devam ederek yaşamın sonraki yıllarını olumsuz etkileyebilir. ${ }^{18}$ Özellikle, okullarda ve adölesan dönemdeki bireylerde sağlıklı beslenme davranışlarının kazanılması hayati önem arz etmektedir. Bu nedenle, genç ve ergenlerde sebze ve meyve tüketimin etkileyen faktörlerin belirlenmesi, 
yetersiz tüketimin nedenlerinin araştırılması gerekmektedir. $^{12-16}$

$\mathrm{Bu}$ çalışmanın ilk amacı ortaokul ve lisede öğrenim gören adölesanların günlük sebze ve meyve tüketimi miktarları, TTM sebze ve meyve tüketimi değişim aşamalarına göre dağılımları ve değişim süreçleri ile ilişkili faktörlerin belirlenmesidir.

\section{GEREÇ VE YÖNTEM}

Bu araştırma 2016 yılında Fethiye İlçe Milli Eğitim Müdürlüğüne bağlı dört ortaokul ve üç liselerde tanımlayıcı tipte bir araştırma olarak gerçekleştirilmiştir. Evrende birey sayısı biliniyor ise formülü ile yedi okuldan toplam en az 1513 kişi örneklem gerektiği hesaplanmıştır. Ayrıca örneklemdeki bireylerin çalışmaya katılmama durumları göz önüne alınmış ve örneklem arttırılarak toplam 1870 kişiden veriler toplanmıştır.

Araştırmaya başlamadan önce Muğla Sitk1 Koçman Üniversitesi Etik Kurulundan Etik Kurul Onayı ve yetkili eğitim otoritesinden kurum izinleri alınmıştır. Yapılan araştırmada çalışmadan önce araştırmaya katılan her öğrenciden, okuldan ve ailesinden verilen cevapların gizli tutulacağ söylenip sözel onam alınmıştır.

Araştırmanın verilerinin toplanmasında, araştırmacılar tarafından ilgili literatür doğrultusunda hazırlanan yedi kapalı uçlu sorudan oluşan tanıtıcı bilgi formu, altı sorudan oluşan sebzemeyve tüketimine ilişkin bilgi formu, TTM sebzemeyve tüketimi değişim aşamaları ve değişim süreci ölçekleri kullanılmıştır. Tanıtıcı bilgi formu, öğrencilerin yaş, cinsiyet, sınıf, kardeş sayısı, öğrencilerin annesinin ve babasının eğitim durumları ve ailenin ekonomik durumu bilgilerini içermektedir. Literatür doğrultusunda hazırlanan sebze ve meyve tüketimine ilişkin bilgi formu sebze ve meyve tüketiminde aile ve arkadaş motivasyonu, evde ve okulda sebze-meyve bulunma durumu, günlük sebze ve meyve tüketim miktarları gibi altı sorudan oluşmaktadır.

TTM sebze ve meyve tüketimi değişim aşamaları, modelin çekirdek yapısını oluşturan değişism aşamaları beş seçenekli tek bir sorudan oluşmaktadır. Günde beş porsiyon sebze meyve tüketenlerin ne kadar süre ile bunu yaptıkları (bir ay veya altı ay), tüketmeyenlerin ise bu konudaki başlama niyeti ve zamanını değerlendirir. İlk aşama olan düşünmeme aşamasında, günde beş porsiyon sebze meyve yemiyorum, gelecek altı ay içinde de yemeyi düşünmüyorum yanıtını verenler bulunmaktadır. Düşünmede, günde beş porsiyon sebze meyve yemeyen, fakat gelecek altı ay içinde yemeyi düşünenlerden oluşmaktadır. Hazırlık aşamasında ise günde beş porsiyon sebze meyve yemiyorum, fakat gelecek bir ay içinde yemeyi düşünüyorum cevabını verenler yer almaktadır. Davranış değişiminin başladığı hareket aşamasında, günde beş porsiyon sebze meyveyi bir aydan beri düzenli olarak tüketenler bulunmaktadır. Son aşama olan devam ettirmede ise günde beş porsiyon sebze meyveyi altı aydan daha uzun süredir tüketme davranışına sahip olan bireylerden oluşmaktadır. ${ }^{10}$

Sebze ve Meyve Tüketimi Değişim Süreci Ölçeği (DSÖ) "geçen ayı düşünerek aşağıdaki ifadelere ne kadar katıldığınızı belirtiniz?" sorusuna; "Hiç katılmıyorum", "Katılmıyorum", "Kararsızım", "Kismen katıliyorum", "Tamamen katılıyorum" gibi seçeneklerden oluşan beşli likert tipte bir ölçektir. TTM Sebze Meyve tüketimi Değişim Süreci Ölçeği, Dinoia ve arkadaşları tarafından 2006 yılında geliştirilmiştir. Toplam 19 madde ve iki alt boyuttan oluşan ölçeğin, bilişsel alt boyutunda yedi $(\alpha=0,77)$, davranışsal alt boyutunda ise 12 ifade yer almaktadır $(\alpha=0,89)$. Puanların yüksek olması değişim konusunda başarılı olma şansının yüksek olduğunu gösterir. Sebze ve meyve tüketimi değişim süreci ölçeğinin bilişsel sürecinden alınabilecek en yüksek puan 35, en düşük puan 7'dir. Davranışsal süreçten alınabilecek en yüksek puan 60 iken en düşük puan ise $12^{\text {' }}$ dir. ${ }^{10}$ Ölçeğin Türk kültürüne uyarlanması Erol, Ergün ve Kadığlu tarafindan yapılmış, 2 faktörlü bilişsel ve davranışsal süreçler geçerli ve güvenilir bulunmuştur. Ölçeğin güvenilirlik bulguları; bilişsel süreçler alt boyutu için 0,79 , davranışsal süreçler için 0,90 olarak ölçülmüştür. ${ }^{19}$

Araştırma verileri okul yönetiminin izin verdiği saatlerde öğrencilerin sınıflarında yüz yüze anket formu ile toplanmıştır. Veri toplama sürecinde araştırmacılar tarafından daha önce iki oturum eğitim verilmiş Sağlık Bilimleri Fakültesi Hemşirelik Bölümü dördüncü sınıf öğrencileri anketör olarak görevlendirilmiştir. Veri toplama süreci yaklaşık bir ay sürmüștür ve her anketin bir öğrenci tarafından doldurulması için yaklaşık yedi dakika sürmüştür. Verilerin analizinde ise, sayı, yüzdelik dilimler, normallik testi, ikili değişkenlerin analizinde bağımsız değişkenlerde $t$ testi ve üç veya daha fazla değişken olduğunda ise Tek Yönlü Varyans Analizi kullanılmıştır. Tüm istatistiksel analizlerde anlamlılık düzeyi olarak $\mathrm{p}<0,05$ değeri kullanılmıştır. 


\section{BULGULAR}

Katılımcıların yaşları 11-17 arasında, \% 59,4'ü erkek, yaklaşık 2/3'ü ortaokul öğrencisidir. Ebeveynlerinin eğitim durumları incelendiğinde çoğunluğunun ilköğretim ve lise düzeyinde eğitim aldıkları, katılımcıların yarıdan çoğunun iki veya üç kardeşinin olduğu belirlenmiştir. Katılımcıların aile ekonomik durumları incelendiğinde orta ve iyi düzeyde olanların büyük çoğunluğu oluşturduğu görülmektedir (Tablo 1).

Her beş öğrenciden dördünün sebze ve meyve tüketme konusunda aile, her dört öğrenciden birinin ise arkadaş motivasyonuna sahip olduğu, büyük çoğunluğunun evlerinde sebze ve meyve bulunduğu, ancak öğrenim gördükleri okullarda bu oranın çok düşük olduğu saptanmıştır. Katılımcıların çok küçük bir oranı günlük hiç sebze ve meyve tüketmediğini belirtirken, 2/3'ünün 1-3 porsiyon arası sebze ve meyve tükettikleri görülmektedir. Öğrencilerin dörtte biri gelecek altı ay boyunca günde beş porsiyon sebze ve meyve tüketmeyi düşünmemekte, beşte biri düşünmekte ancak kendini hazır hissetmemekte ve beşte biri ise bir ay içinde günde düzenli olarak beş porsiyon sebze ve meyve tüketimi için kendilerini hazır hissetmektedirler. Transteoretik model değişim aşamalarına göre, bir aydan fazladır düzenli olarak günde beş porsiyon sebze ve meyve tüketen öğrencilerin oranı ise $\% 32,1$ 'dir (Tablo 1).

Öğrencilerin yaşlarına, sınıflarına, ailelerinin ekonomik durumları ile değişim süreci ölçeğinin bilişsel ve davranışsal süreç boyutlarından aldıkları puan ortalamalarının karşılaştırması sonucunda da gruplar arasında istatistiksel olarak anlamlı farklılık saptanmıştır ( $<<0,01)$ (Tablo 2). Ayrıca, davranışsal süreçte kardeş sayısına göre yapılan karşılaştırmalarda gruplararası anlamlı farklılık saptanırken $(\mathrm{p}=0,011)$, bilişsel süreçte kardeş sayısına göre istatistiksel olarak anlamlı farklılık bulunmamaktadır ( $\mathrm{p}>0,05)$.

Bilişsel süreçte yapılan çoklu karşılaştırmalar sonucunda, 11 yaşındakilerin bilişsel süreç puanları 12, 14, 15, 16 ve 17 yaşındakilere, 12 yaşındakilerin bilişsel süreç puanları 14, 15, 16 ve 17 yaşındakilere, 13 yaşındakilerin bilişsel süreç puanları 14, 15, 16 ve 17 yaşındakilere, 14 yaşındakilerin bilişsel süreç puanları 15, 16 ve 17 yaşındakilere göre daha yüksek ve anlamlıdır. Ancak, 15, 16 ve 17 yaşındakilerin bilişsel süreç puanları arasında istatistiksel olarak anlamlı farklılık saptanmamıştır. Davranışsal süreçte, yapılan çoklu karşılaştırmalar sonucunda, 11, 12 ve 13 yaşındakilerin davranışsal süreç puanları 14, 15, 16 ve 17 yaşıındakilere, 14 yaşındakilerin puanları 16 ve 17 yaşındakilere göre daha yüksek ve anlamlıdır. Ancak, 16 ve 17 yaşındakilerin davranışsal süreç puanları arasında ve 11,12 ve 13 yaşındakilerin davranışsal süreç puan ortalamaları arasında da istatistiksel olarak anlamlı farklılık saptanmamıştır.

Öğrencilerin sınıflarına göre bilişsel süreçte yapılan çoklu karşılaştırmalar sonucunda 5, 6 ve 7 . sinıfların puan ortalamaları $9,10,11$ ve 12 sinifların puan ortalamalarına, 8. sinifların puan ortalamaları 9, 10, 11 ve 12 siniflarin puan ortalamalarina, 9. sinıfların puan ortalamaları 10,11 ve 12 sinifların puan ortalamalarına, 10. sinifların puan ortalamaları 11 ve 12 sinıfların puan ortalamalarına, göre daha yüksek ve istatistiksel olarak anlamlıdır. Ancak, 5, 6 ve 7 . sinıfların puan ortalamaları arasında ve 11 ve 12. sinıfların puan ortalamaları arasında istatistiksel olarak anlamlı farklılık saptanmamıştır. Ayrıca, davranışsal süreçte 5-8. sinıfların puan ortalamalarının 9-12. sınıflara göre daha yüksek, 6 . sınıfların puan ortalamalarının 8. sınıflara göre daha yüksek ve istatistiksel olarak anlamlı farklılık saptanmıştır. Ancak, 5, 7 ve 8. sınıfların ve 9, 10, 11 ve 12. sinifların puan ortalamaları arasinda istatistiksel olarak anlamlı farklılık saptanmamıştır.

Bilişsel süreçte yapılan çoklu karşılaştırmalar sonucunda, ekonomik durumu çok iyi ve iyi olanların orta ve kötü ekonomik düzeye göre daha yüksek ve ayrıca, ekonomik durumu orta olanların ve kötü ekonomik düzeye göre daha yüksek ve istatistiksel olarak anlamlı olduğu belirlenmiştir. Ancak, ekonomik düzeyi çok iyi olanlar ile iyi olanların puan ortalamaları arasında istatistiksel olarak anlamlı farklılık saptanmamıştır (Tablo 2).

Davranışsal süreçte, yapılan çoklu karşılaştırmalar sonucunda, ekonomik durumu çok iyi olanların iyi, orta ve kötü ekonomik düzeye göre daha yüksek, ekonomik durumu iyi olanların orta ve kötü ekonomik düzeye göre daha yüksek ve istatistiksel olarak anlamlı olduğu belirlenmiştir. Ancak, ekonomik düzeyi orta olanlar ile kötü olanların puan ortalamaları arasında istatistiksel olarak anlamlı farklılık saptanmamıştır (Tablo 2). Kardeş sayısı açısından bakıldığında, davranışsal süreçte, yapılan çoklu karşılaştırmalar sonucunda, kardeş sayısı dörtten az olanların dört ve daha fazla kardeşi olanlara göre puan ortalamalarının daha yüksek ve istatistiksel olarak anlamlı olduğu belirlenmiştir (Tablo 2). Hem bilişsel hem de davranışsal süreç boyutlarında anne ve baba eğitim düzeyi ile sebze ve meyve tüketimi değişim süreci ölçeği puan ortalamalarının karşılaştırılması sonucunda 
istatistiksel olarak anlamlı farklılık olduğu belirlenmiştir (Tablo 2). Yapılan çoklu karşılaştırmalar sonucunda, anne eğitim düzeyi ilkokula göre ortaokul ve lise; baba eğitim düzeyi ilkokula göre lise ve üniversite olan öğrencilerin hem bilişsel hem de davranışsal süreç puan ortalamalarının yüksek ve istatistiksel olarak anlamlı olduğu saptanmıştır (Tablo 2).

Katılımcıların cinsiyetleri ile değişim süreci ölçeği bilişsel ve davranışsal süreç puan ortalamaları karşılaştırılmış hem bilişsel $(\mathrm{p}<0,01)$ hem de davranışsal süreç $(\mathrm{p}<0,01)$ boyutunda kızların puan ortalamalarının erklerden daha yüksek ve istatistiksel olarak anlamlı olduğu saptanmıştır (p $<0,01$ ) (Tablo 3). Öğrencilerden aile ve arkadaş motivasyonuna sahip olmaları ile değişim süreci ölçeği bilişsel ve davranışsal süreç puan ortalamaları karşılaştırılmış hem bilişsel hem de davranışsal süreç boyutunda aile ve arkadaş motivasyonuna sahip olanların puan ortalamalarının olmayanlara göre daha yüksek ve istatistiksel olarak anlamlı olduğu saptanmıştır $(\mathrm{p}<0,05)$ (Tablo 3). Ayrıca, öğrencilerin bulundukları ortamlar olan evde ve okulda sebze-meyveye erişme imkanları ile değişim süreci ölçeği bilişsel ve davranışsal süreç puan ortalamalarının karşılaştırılması sonucunda da hem bilişsel hem de davranışsal süreç boyutunda hem okulda hem de evde sebze-meyveye erişebilen ögrrencilerin puan ortalamalarının evde ve okulda sebzeye erișemeyenlere göre daha yüksek ve istatistiksel olarak anlamlı olduğu saptanmıştır $(\mathrm{p}<$ 0,05) (Tablo 3).

Günlük sebze ve meyve tüketim porsiyon sayısı ile değişim süreci ölçeğinin bilişsel ve davranışsal süreç boyutlarının karşılaştırılması sonucunda ve ögrencilerin sebze ve meyve tüketimi değişim aşamalarına göre yapılan karşılaştırmalar sonucunda gruplar arasında istatistiksel olarak anlamlı farklılık saptandığı görülmektedir (Tablo 4). Yapılan çoklu karşılaştırmalar sonucunda, günlük sebze ve meyve tüketim porsiyon sayısı $3-5$ ve 1-2 porsiyon arasında olan öğrencilerin hiç sebze tüketmeyenlere göre, 3-5 porsiyon tüketenlerin de 12 porsiyon arası tüketenlere göre hem bilişsel hem de davranışsal süreç puan ortalamalarının daha yüksek ve istatistiksel olarak anlamlı olduğu saptanmıştır ( $p$ $<0,01)$.

TTM sebze ve meyve tüketimi değişim aşamaları ile değişim süreci ölçeğinin bilişsel ve davranışsal süreç boyutlarının karşılaştırılması sonucunda da istatistiksel olarak anlamlı farklılık olduğu belirlenmiştir (Tablo 4). Değişim süreci ölçeği ile TTM sebze ve meyve tüketimi değişim aşamaları arasında yapılan çoklu karşılaştırmalar sonucunda, hem bilişsel $(\mathrm{p}=0,005)$ hem de davranışsal $(\mathrm{p}=$ 0,009) süreçte hareket aşamasının puan ortalamalarının düşünmeme aşamasından daha yüksek ve istatistiksel olarak anlamlı olduğu saptanmıştır.

\section{TARTIŞMA}

Ortaokul ve lise öğrencilerinden oluşan 1780 kişi ile yürütülen bu çalışmada, katılımcıların yarısının günde beş porsiyondan az sebze ve meyve tükettiği, kızların erkeklerden, yaşı ve öğrenim gördüğü sınıfı daha küçük olanların yüksek sınıflardan, kardeş sayısı üçten az olanların daha fazla olanlardan, ekonomik düzeyi daha iyi olanların orta ve kötü olanlardan, aile ve arkadaş motivasyonuna sahip olanların olmayanlardan, evde veya okulda sebze ve meyveye erişebilenlerin erişemeyenlerden daha fazla sebze ve meyve tükettiği saptanmıştır. Ayrıca TTM değişim aşamalarına göre katılımcıların düzenli olarak 1/3'ünün sebze ve meyve tükettiği, hareket aşamasındaki öğrencilerin düşünmeme aşamasındakilere göre ileri düzeyde sebze ve meyve tüketim davranışına sahip olduğu, günlük tüketilen sebze ve meyve porsiyon sayısının bu davranışla ilişkili olduğu belirlenmiştir.

Katılımcıların çok küçük bir oranı günlük hiç sebze ve meyve tüketmediğini belirtirken, $\% 54,9$ 'unun iki porsiyon ve daha az sebze ve $\% 46,1$ 'inin iki porsiyon ve daha az meyve tükettikleri görülmektedir. $\mathrm{Bu}$ bilgiler 1şı̆̆ında katılımcıların yarısının günlük beş porsiyondan az sebze ve meyve tükettikleri söylenebilir. Literatürdeki çalışmalarla karşılaştırıldığında çalışmamızdaki önerilen günlük sebze ve meyve tüketiminin daha yüksek oranda olduğu görülmektedir. ${ }^{12-16} \mathrm{Bu}$ durum çalışmanın yapıldığ 1 bölgenin tarıma elverişli topraklara sahip olmasına ve bireylerin temel geçim kaynağının tarım ve sera işciliği olmasına bağlı olabilir.

Literatürdeki çalışmalara paralel olarak bu çalışmada da, günlük sebze ve meyve tüketim miktarının beş porsiyondan daha fazla olmasının hem sebze ve meyve tüketim davranışlarını hem de TTM değişim aşamalarının ileri seviyelerinde olma durumunu pozitif etkilediği görülmektedir. ${ }^{8-11}$ Ayrıca, çalışmada TTM sebze ve meyve tüketimi değişim aşamalarından hareket aşamasının hem bilişsel hem de davranışsal süreç puan ortalamalarının düşünmeme aşamasından daha yüksek ve istatistiksel olarak anlamlı olduğu saptanmıştır. Bu sonuç, sebze ve meyve tüketimi ile TTM değişim aşamaları ve değişim süreçleri arasındaki teorik ilişkiyi doğrular niteliktedir. ${ }^{8-11}$ 


\begin{tabular}{|c|c|c|c|}
\hline Değişkenler & Kategoriler & $\mathbf{n}$ & $\%$ \\
\hline \multirow{7}{*}{ Yaş (Y1l) } & 11 & 356 & 19,0 \\
\hline & 12 & 268 & 14,3 \\
\hline & 13 & 189 & 10,1 \\
\hline & 14 & 190 & 10,2 \\
\hline & 15 & 312 & 16,7 \\
\hline & 16 & 254 & 13,6 \\
\hline & 17 & 301 & 16,1 \\
\hline \multirow{2}{*}{ Cinsiyet } & $\mathrm{K} 1 \mathrm{z}$ & 759 & 40,6 \\
\hline & Erkek & 1111 & 59,4 \\
\hline \multirow{8}{*}{ Sinif } & 5. & 413 & 22,1 \\
\hline & 6. & 403 & 21,6 \\
\hline & 7. & 275 & 14,7 \\
\hline & 8. & 125 & 6,7 \\
\hline & 9. & 222 & 11,9 \\
\hline & 10. & 121 & 6,5 \\
\hline & 11. & 175 & 9,4 \\
\hline & 12. & 136 & 7,3 \\
\hline \multirow{4}{*}{ Kardeş sayısı } & 1 & 221 & 11,8 \\
\hline & 2 & 875 & 46,8 \\
\hline & 3 & 576 & 30,8 \\
\hline & 4 ve üzeri & 198 & 10,6 \\
\hline \multirow{5}{*}{ Anne eğitim durumu } & Okur-yazar & 99 & 5,3 \\
\hline & İlkokul & 760 & 40,6 \\
\hline & Ortaokul & 455 & 24,3 \\
\hline & Lise & 441 & 23,6 \\
\hline & Üniversite & 115 & 6,1 \\
\hline \multirow{5}{*}{ Baba eğitim durumu } & Okur-yazar & 63 & 3,4 \\
\hline & İlkokul & 549 & 29,4 \\
\hline & Ortaokul & 469 & 25,1 \\
\hline & Lise & 561 & 30,0 \\
\hline & Üniversite & 228 & 12,2 \\
\hline \multirow{4}{*}{ Ekonomik durum } & Çok iyi & 174 & 9,3 \\
\hline & İyi & 863 & 46,1 \\
\hline & Orta & 721 & 38,6 \\
\hline & Kötü & 112 & 6,0 \\
\hline \multirow{2}{*}{ Aile motivasyonu } & Evet & 1494 & 79,9 \\
\hline & Hayır & 376 & 20,1 \\
\hline \multirow{2}{*}{ Arkadaş motivasyonu } & Evet & 480 & 25,7 \\
\hline & Hayır & 1390 & 74,3 \\
\hline \multirow{2}{*}{ Evde sebze meyve bulunma durumu } & Evet & 1547 & 82,7 \\
\hline & Hayır & 323 & 17,3 \\
\hline \multirow{2}{*}{ Okulda sebze meyve bulunma durumu } & Evet & 191 & 10,2 \\
\hline & Hayır & 1679 & 89,8 \\
\hline \multirow{6}{*}{ Günlük sebze tüketim miktarı } & Hiç yemiyor & 118 & 6,3 \\
\hline & Bir porsiyon & 561 & 30,0 \\
\hline & İki porsiyon & 465 & 24,9 \\
\hline & Üç porsiyon & 314 & 16,8 \\
\hline & Dört porsiyon & 179 & 9,6 \\
\hline & Beş porsiyon ve üzeri & 233 & 12,5 \\
\hline \multirow{6}{*}{ Günlük meyve tüketim miktarı } & Hiç yemiyor & 92 & 4,9 \\
\hline & Bir porsiyon & 428 & 22,9 \\
\hline & İki porsiyon & 433 & 23,2 \\
\hline & Üç porsiyon & 386 & 20,6 \\
\hline & Dört porsiyon & 209 & 11,2 \\
\hline & Beş porsiyon ve üzeri & 322 & 17,2 \\
\hline \multirow{5}{*}{ Değişim aşamaları } & Düşünmeme & 460 & 24,6 \\
\hline & Düşünme & 427 & 22,8 \\
\hline & Hazırlık & 383 & 20,5 \\
\hline & Hareket & 282 & 15,1 \\
\hline & Devam Ettirme & 318 & 17,0 \\
\hline
\end{tabular}




\begin{tabular}{|c|c|c|c|c|c|c|c|}
\hline Ölçekler & Değişkenler & Kategoriler & $\mathrm{n}$ & $\overline{\mathrm{X}}$ & SS & F & $\mathrm{P}$ \\
\hline \multirow{31}{*}{ Bilişsel süreç } & \multirow{7}{*}{ Yaş (Y1l) } & 11 & 356 & 26,87 & 5,62 & \multirow{7}{*}{45,56} & \multirow{7}{*}{$* *<0,001$} \\
\hline & & 12 & 268 & 28,27 & 4,83 & & \\
\hline & & 13 & 189 & 27,48 & 6,07 & & \\
\hline & & 14 & 190 & 24,84 & 5,80 & & \\
\hline & & 15 & 312 & 23,17 & 5,83 & & \\
\hline & & 16 & 254 & 22,70 & 5,95 & & \\
\hline & & 17 & 301 & 22,89 & 6,06 & & \\
\hline & \multirow{8}{*}{ Sinif } & 5. & 413 & 26,14 & 6,04 & \multirow{8}{*}{28,64} & \multirow{8}{*}{$* *<0,001$} \\
\hline & & 6. & 403 & 27,18 & 4,90 & & \\
\hline & & 7. & 275 & 26,60 & 6,07 & & \\
\hline & & 8. & 125 & 24,05 & 5,80 & & \\
\hline & & 9. & 222 & 23,30 & 5,82 & & \\
\hline & & 10. & 121 & 21,85 & 6,80 & & \\
\hline & & 11. & 175 & 22,33 & 5,92 & & \\
\hline & & 12. & 136 & 23,10 & 6,26 & & \\
\hline & \multirow{4}{*}{ Ekonomik durum } & Cok iyi & 174 & 26,40 & 6,30 & \multirow{4}{*}{16,67} & \multirow{4}{*}{$* *<0,001$} \\
\hline & & İyi & 863 & 25,78 & 6,02 & & \\
\hline & & Orta & 721 & 24,37 & 5,96 & & \\
\hline & & Kötü & 112 & 22,50 & 6,55 & & \\
\hline & \multirow{4}{*}{ Kardeş sayısı } & 1 & 221 & 24,62 & 7,00 & \multirow{4}{*}{2,44} & \multirow{4}{*}{0,062} \\
\hline & & 2 & 875 & 25,24 & 5,95 & & \\
\hline & & 2 & 576 & 25,38 & 6,00 & & \\
\hline & & 4 ve üzeri & 198 & 24,20 & 6,19 & & \\
\hline & \multirow{4}{*}{ Anne eğitim düzeyi } & İlkokul & 859 & 24,12 & 6,09 & & \\
\hline & & Ortaokul & 455 & 26,36 & 5,95 & & \\
\hline & & Lise & 441 & 25,73 & 5,83 & $15,6 /$ & $F^{*} \times<0,001$ \\
\hline & & Üniversite & 115 & 25,04 & 7,05 & & \\
\hline & & İlkokul & 612 & 24,16 & 6,03 & & \\
\hline & & Ortaokul & 469 & 25,49 & 6,15 & & \\
\hline & Baba egitim duzeyı & Lise & 561 & 25,58 & 5,96 & 1,28 & $2+<0,001$ \\
\hline & & Üniversite & 228 & 25,66 & 6,51 & & \\
\hline & & 11 & 356 & 43,41 & 9,82 & & \\
\hline & & 12 & 268 & 44,31 & 9,79 & & \\
\hline & & 13 & 189 & 42,94 & 10,50 & & \\
\hline & Yaş (Y11) & 14 & 190 & 35,94 & 11,69 & 75,91 & $* *<0,001$ \\
\hline & & 15 & 312 & 33,19 & 10,25 & & \\
\hline & & 16 & 254 & 32,09 & 10,46 & & \\
\hline & & 17 & 301 & 33,01 & 11,21 & & \\
\hline & & 5. & 413 & 40,61 & 11,07 & & \\
\hline & & 6. & 403 & 42,34 & 9,88 & & \\
\hline & & 7. & 275 & 40,00 & 11,42 & & \\
\hline & S & 8. & 125 & 37,36 & 12,14 & 2815 & $* *<0<01$ \\
\hline & Sinit & 9. & 222 & 32,68 & 10,69 & 38,15 & $x<0,001$ \\
\hline & & 10. & 121 & 31,89 & 11,28 & & \\
\hline & & 11. & 175 & 32,27 & 10,47 & & \\
\hline & & 12. & 136 & 32,65 & 11,88 & & \\
\hline Davranışsal süreç & & Çok iyi & 174 & 42,22 & 11,76 & & \\
\hline & & İyi & 863 & 39,51 & 11,51 & & \\
\hline & Ekonomık durum & Orta & 721 & 35,31 & 11,18 & 30,92 & $* *<0,001$ \\
\hline & & Kötü & 112 & 33,95 & 11,33 & & \\
\hline & & 1 & 221 & 38,72 & 12,37 & & \\
\hline & & 2 & 875 & 37,83 & 11,58 & & \\
\hline & Kardeş sayısı & 2 & 576 & 38,28 & 11,54 & 3,70 & $*<0,011$ \\
\hline & & 4 ve üzeri & 198 & 35,35 & 11,36 & & \\
\hline & & İlkokul & 859 & 35,83 & 11,49 & & \\
\hline & & Ortaokul & 455 & 39,23 & 11,45 & & \\
\hline & Anne egitım duzeyı & Lise & 441 & 40,27 & 11,24 & 17,51 & $w *<0,001$ \\
\hline & & Üniversite & 115 & 37,62 & 12,97 & & \\
\hline & & İlkokul & 612 & 36,01 & 11,27 & & \\
\hline & & Ortaokul & 469 & 38,16 & 11,56 & & \\
\hline & Baba egitım duzeyı & Lise & 561 & 39,06 & 11,69 & 7,82 & $F_{*} \times 0,001$ \\
\hline & & Üniversite & 228 & 38,87 & 12,35 & & \\
\hline
\end{tabular}




\begin{tabular}{|c|c|c|c|c|c|c|c|}
\hline Ölçekler & Değişkenler & Kategoriler & $\mathrm{n}$ & $\overline{\mathrm{X}}$ & SS & $\mathrm{t}$ & $\mathrm{P}$ \\
\hline \multirow{10}{*}{ Bilişsel süreç } & \multirow{2}{*}{ Cinsiyet } & $\mathrm{K}_{1 \mathrm{z}}$ & 759 & 26,12 & 5,65 & \multirow{2}{*}{6,01} & \multirow{2}{*}{$<0,001$} \\
\hline & & Erkek & 1111 & 24,40 & 6,34 & & \\
\hline & \multirow{2}{*}{ Aile motivasyonu } & Evet & 1494 & 25,83 & 5,76 & \multirow{2}{*}{10,57} & \multirow{2}{*}{$<0,001$} \\
\hline & & Hayır & 376 & 22,19 & 6,67 & & \\
\hline & \multirow{2}{*}{$\begin{array}{l}\text { Arkadaş } \\
\text { motivasyonu }\end{array}$} & Evet & 480 & 25,85 & 5,92 & \multirow{2}{*}{3,12} & \multirow{2}{*}{0,002} \\
\hline & & Hayır & 1390 & 24,84 & 6,18 & & \\
\hline & \multirow{2}{*}{$\begin{array}{l}\text { Evde sebze-meyve } \\
\text { olma }\end{array}$} & Evet & 1547 & 25,36 & 6,06 & \multirow{2}{*}{4,06} & \multirow{2}{*}{$<0,001$} \\
\hline & & Hayır & 323 & 23,84 & 6,33 & & \\
\hline & \multirow{2}{*}{$\begin{array}{l}\text { Okulda sebze- } \\
\text { meyve olma }\end{array}$} & Evet & 191 & 25,99 & 6,21 & \multirow{2}{*}{2,11} & \multirow{2}{*}{0,034} \\
\hline & & Hayır & 1679 & 25,00 & 6,12 & & \\
\hline \multirow{10}{*}{ Davranışsal süreç } & \multirow{2}{*}{ Cinsiyet } & $\mathrm{K}_{1 \mathrm{z}}$ & 759 & 39,28 & 11,07 & \multirow{2}{*}{4,50} & \multirow{2}{*}{$<0,001$} \\
\hline & & Erkek & 1111 & 36,81 & 11,96 & & \\
\hline & \multirow{2}{*}{ Aile motivasyonu } & Evet & 1494 & 39,08 & 11,30 & \multirow{2}{*}{9,60} & \multirow{2}{*}{$<0,001$} \\
\hline & & Hayır & 376 & 32,77 & 11,76 & & \\
\hline & \multirow{2}{*}{$\begin{array}{l}\text { Arkadaş } \\
\text { motivasyonu }\end{array}$} & Evet & 480 & 40,45 & 10,61 & \multirow{2}{*}{5,79} & \multirow{2}{*}{$<0,001$} \\
\hline & & Hayır & 1390 & 36,90 & 11,88 & & \\
\hline & \multirow{2}{*}{$\begin{array}{l}\text { Evde sebze-meyve } \\
\text { olma }\end{array}$} & Evet & 1547 & 38,16 & 11,66 & \multirow{2}{*}{2,84} & \multirow{2}{*}{0,005} \\
\hline & & Hayır & 323 & 36,14 & 11,60 & & \\
\hline & \multirow{2}{*}{$\begin{array}{l}\text { Okulda sebze- } \\
\text { meyve olma }\end{array}$} & Evet & 191 & 41,06 & 11,08 & \multirow{2}{*}{4,07} & \multirow{2}{*}{$<0,001$} \\
\hline & & Hayır & 1679 & 37,44 & 11,68 & & \\
\hline
\end{tabular}

\begin{tabular}{|c|c|c|c|c|c|c|c|}
\hline Ölçekler & Değişkenler & Kategoriler & $\mathrm{n}$ & $\bar{X}$ & $\mathrm{SS}$ & $\mathrm{F}$ & $\mathrm{P}$ \\
\hline \multirow{11}{*}{ Bilişsel süreç } & \multirow{3}{*}{$\begin{array}{l}\text { Günlük sebze } \\
\text { tüketim miktarı }\end{array}$} & Hiç tüketmiyor & 118 & 20,64 & 6,99 & \multirow{3}{*}{92,99} & \multirow{3}{*}{$<0,001$} \\
\hline & & 1-2 porsiyon & 1026 & 24,15 & 5,84 & & \\
\hline & & $3-5$ porsiyon & 726 & 27,17 & 5,66 & & \\
\hline & \multirow{3}{*}{$\begin{array}{l}\text { Günlük meyve } \\
\text { tüketim miktarı }\end{array}$} & Hiç tüketmiyor & 92 & 20,76 & 7,37 & \multirow{3}{*}{86,81} & \multirow{3}{*}{$<, 001$} \\
\hline & & 1-2 porsiyon & 861 & 23,75 & 5,79 & & \\
\hline & & $3-5$ porsiyon & 917 & 26,81 & 5,77 & & \\
\hline & \multirow{5}{*}{ Değişim aşamaları } & Düşünmeme & 460 & 24,34 & 5,82 & \multirow{5}{*}{3,29} & \multirow{5}{*}{,011 } \\
\hline & & Düşünme & 427 & 25,06 & 5,36 & & \\
\hline & & Hazırlık & 383 & 25,23 & 5,75 & & \\
\hline & & Hareket & 282 & 25,95 & 6,64 & & \\
\hline & & Devam ettirme & 318 & 25,34 & 7,31 & & \\
\hline \multirow{11}{*}{ Davranışsal süreç } & \multirow{3}{*}{$\begin{array}{l}\text { Günlük sebze } \\
\text { tüketim miktarı }\end{array}$} & Hiç tüketmiyor & 118 & 28,32 & 10.64 & \multirow{3}{*}{93,39} & \multirow{3}{*}{$<, 001$} \\
\hline & & $1-2$ porsiyon & 1026 & 36,27 & 11,43 & & \\
\hline & & 3-5 porsiyon & 726 & 41,54 & 10,77 & & \\
\hline & \multirow{3}{*}{$\begin{array}{l}\text { Günlük meyve } \\
\text { tüketim miktarı }\end{array}$} & Hiç tüketmiyor & 92 & 29,23 & 11,77 & \multirow{3}{*}{98,26} & \multirow{3}{*}{$<, 001$} \\
\hline & & 1-2 porsiyon & 861 & 35,05 & 11,19 & & \\
\hline & & $3-5$ porsiyon & 917 & 41,26 & 10,96 & & \\
\hline & \multirow{5}{*}{ Değişim aşamaları } & Düşünmeme & 460 & 36,83 & 11,75 & \multirow{5}{*}{2,90} & \multirow{5}{*}{,021 } \\
\hline & & Düşünme & 427 & 37,97 & 10,93 & & \\
\hline & & Hazırlık & 383 & 37,82 & 11,05 & & \\
\hline & & Hareket & 282 & 39,73 & 11,21 & & \\
\hline & & Devam ettirme & 318 & 37,31 & 13,37 & & \\
\hline
\end{tabular}

$\overline{\mathrm{X}}=$ Ortalama. SS= Standart sapma. $\mathrm{F}=$ Tek Yönlü Varyans Analizi. ${ }^{* *} \mathrm{p}<, 01$ ve $* \mathrm{p}<, 05$ istatistiksel anlamlılık düzeyi 
Çalışmada, bilişsel ve davranışsal süreç boyutunda kızların puan ortalamaları erkeklerden daha yüksek ve istatistiksel olarak anlamlıdır. Adölesan dönemdeki kızların erkeklerden daha fazla sebze ve meyve tüketim davranışlarına sahip olduğu literatürdeki çalışmalarda da açıkça ortadadır. ${ }^{13,20}$ Fiziksel görünümün önemli olduğu adölesan dönemde kilo alımını azaltmak için kız öğrencilerin kalori değeri düşük olan için sebze ve meyve tüketimine erkeklere göre daha fazla ağırlık verebilecekleri düşünülmektedir. Sebze ve meyve tüketiminde yaşın etkisi yapılan çalışmalarda da ortaya konmuştur. Özellikle daha küçük yaşlardaki öğrencilerin büyük sınıflara göre sağlıklı beslenme ve düzenli olarak sebze ve meyve tüketim davranışlarına sahip oldukları belirtilmektedir. ${ }^{13-16}$ Çalışmamızda da, yaşı küçük olan öğrencilerin daha ileri yaştakilere, daha alt sınıfta öğrenim gören öğrencilerin üst sinıflardakilere göre daha fazla sebze ve meyve tüketimi davranışına sahip olduğu belirlenmiştir. $\mathrm{Bu}$ durum beslenme konusunda küçük yaşlarda ebeveyn ve öğretmen kontrolünün daha fazla olmasına bağlı olabilir. Yaş büyüdükçe aile ve ögretmenin yerini akranlardan etkilenmenin aldığı söylenebilir.

Yapılan bazı çalışmalarda bireysel ve sosyal faktörlerin sebze ve meyve tüketiminde orta düzeyde etkisi olduğu, ancak ekonomik durumun sebze ve meyve tüketimi miktarı ile ilişkili olduğu ortaya koymaktadır. ${ }^{21}$ Ancak, başka bir çalışmada ise sebze ve meyve tüketimi ile ekonomik durum arasında bir ilişki olmadığı belirtilmektedir. ${ }^{22} \mathrm{Bu}$ çalışmada da, ailesinin ekonomik düzeyi daha iyi durumda olan öğrencilerin özellikle orta ve alt gelir grubundaki öğrencilere göre daha fazla sebze ve meyve tüketimi davranışına sahip olduğu sonucuna ulaşılmıştır. Ayrıca, çalışmamızda ebeveynlerin eğitim düzeyi arttıkça sebze ve meyve tüketimi davranışları da artmaktadır. Ekonomik düzeyin ve ebeveyn eğitim düzeyi gibi sosyal faktörlerin sebze ve meyveye erişmede ve tüketmede önemli birer faktör oldukları ve diğer faktörlerle birlikte öğrencilerin sebze ve meyve tüketimi davranışlarını etkiledikleri söylenebilir.

Aile çevresi, arkadaş etkisi, yaşanılan yer, ekonomik yapı gibi bazı psikolojik, sosyal ve çevresel faktörlerin sağlığı geliştirme ve sağlıklı beslenme davranışlarında etkili olduğu yapılan çalışmalarda belirtilmektedir. Bu çalışmalarda sebze ve meyve tüketimi gibi sağlığ 1 geliştirici bir davranışında bu faktörlerden etkilendiği ortaya koymaktadır. ${ }^{22-23}$ Çalışmamızda da davranışsal süreç boyutunda aile ve arkadaş motivasyonuna sahip olanların puan ortalamalarının olmayanlara göre daha yüksek ve istatistiksel olarak anlamlı olduğu görülmektedir. Ebeveynlerin sosyokültürel düzeylerinin artması ile birlikte ailedeki tüm bireylerde sağlıklı beslenme konusunda farkındalık artmakta ve ebeveynler çocuklarına iyi birer rol model olmaktadır. $\mathrm{Bu}$ sonuçlar 1şığında düzenli sebze ve meyve tüketiminde aile ve arkadaş desteği ve katkısının olmasının önemli bir faktör olduğu söylenebilir.

Çalışmamızda evde ve okulda sebze ve meyve bulunma durumunun tüketim miktarını, tüketim davranışlarını etkilediği önemli bulgularımızdan biridir. Evde sebze ve meyve bulunmasının önemli olduğu, özellikle okullarda sebze ve meyveye erişimin sağlanmasının çocukların tüketimini etkilediği belirtilmiştir. ${ }^{24,} 25$ Çocukların yaşadıkları, öğrenim gördükleri, oynadıkları ve boş zamanlarını geçirdikleri çeşitli alanlarda sebze ve meyve bulunmasinın onların davranışlarını önemli derecede etkileyeceği söylenebilir.

\section{SONUÇ}

Çalışma sonucunda, erkeklerin, 15 yaş üzerindeki ve liselerdeki adölesanların sebze ve meyve tüketimin yetersiz olduğu; ekonomik durum, aile ve arkadaş etkisi, sebze ve meyveye erişim gibi faktörlerin tüketimde etkili olduğu; günlük tüketilen porsiyon sayısının sebze ve meyve tüketim davranışıyla ilişkili olduğu belirlenmiştir. Bu sonuçlar ışığında, yaşı daha büyük, ileri sınıflarda öğrenim gören, cinsiyeti erkek olan, ekonomik yetersizliği olan öğrencilere yönelik sağlığı geliştirici uygulamalar ve destekleyici çevrenin oluşturulması önerilmektedir. Bir başka önerimiz ise, özellikle aile, okul, arkadaş, öğretmen, sağlık kurumları gibi destekleyici bireysel ve kurumsal çevrenin oluşturulması, öğrencilerin bulundukları ortamlarda sebze ve meyveye erişimlerinin kolaylaştırılmasıdır.

\section{TEŞEKKÜR}

Çalışmamızda anketör olarak görev alan öğrencilerimize, işbirliği içinde çalıştığımız okullardaki öğretmen ve yöneticilere, en önemlisi de çalışmamıza katkılarından dolayı katılımcı öğrencilerimize teşekkürlerimizi sunarız.

\section{KAYNAKLAR}

1. Boeing $\mathrm{H}$, Bechthold $\mathrm{A}$, Bub A, Ellinger S, Haller D, Kroke A, et al. Critical review: vegetables and fruit in the prevention of chronic 
diseases. European Journal of Nutrition 2012; 51: 1-27.

2. Boffetta P, Couto E, Wichmann J, Ferrari P, Trichopoulos D, Bueno-de-Mesquita HB, et al. Fruit and vegetable intake and overall cancer risk in the European Prospective Investigation into Cancer and Nutrition (EPIC). Journal of the National Cancer Institute 2010; 102(8): 529537.

3. Hartley L, Igbinedion E, Thorogood M, Clarke A, Stranges S, Hooper L, et al. Increased consumption of fruit and vegetables for the primary prevention of cardiovascular diseases. Cochrane Database Syst Rev 2013; 6: $1-55$.

4. Redding CA, Rossi JS, Rossi SR, Velicer WF, Prochaska JO. Health behavior models. In International Electronic Journal of Health Education, 2010; 3:180-193.

5. Prochaska JO, Velicer WF. The transtheoretical model of health behavior change. American Journal of Health Promotion 1997; 12(1): 3848.

6. Erol S, Erdoğan S. Sağlık davranışlarını geliştirmek ve değiştirmek için transteoretik modelin kullanılması. Anadolu Hemşirelik ve Sağlık Bilimleri Dergisi 2007; 10: 86-94.

7. Prochaska JO. Strong and weak principles for progressing from precontemplation to action on the basis of twelve problem behaviors. Health Psychology 1994; 13(1): 47.

8. Hildebrand DA, Betts NM. Assessment of stage of change, decisional balance, self-efficacy, and use of processes of change of low-income parents for increasing servings of fruits and vegetables to preschool-aged children. Journal of Nutrition Education and Behavior 2009; 41(2): 110-119.

9. Horwath CC, Nigg CR, Motl RW, Wong KT, Dishman RK. Investigating fruit and vegetable consumption using the transtheoretical model. American Journal of Health Promotion 2010; 24(5): 324-333.

10. Di Noia J, Schinke SP, Prochaska JO, Contento IR. Application of the transtheoretical model to fruit and vegetable consumption among economically disadvantaged African-American adolescents: preliminary findings. American Journal of Health Promotion 2006; 20(5): 342348.

11. Mao C, Xu L, Xu L, Ma H, Liu T, Qu X, et al. Assessment of fruit and vegetable intake behavior among adolescents in Hangzhou, China. Indian Journal of Pediatrics 2012; 79 (9):1218-1223.
12. Gross SM, Pollock ED, Braun B. Family influence: Key to fruit and vegetable consumption among fourth-and fifth-grade students. Journal of Nutrition Education and Behavior 2010; 42(4): 235-241.

13. Lorson BA, Melgar-Quinonez HR, Taylor CA. Correlates of fruit and vegetable intakes in US children. Journal of the American Dietetic Association 2009; 109(3): 474-478.

14. Rieth MA, Moreira MB, Fuchs FD, Moreira LB, Fuchs SC. Fruits and vegetables intake and characteristics associated among adolescents from Southern Brazil. Nutrition Journal 2012; 11(1): 95.

15. Aksoydan E, Cakir N. Adolesanların beslenme alışkanlıkları, fiziksel aktivite düzeyleri ve vücut kitle indekslerinin değerlendirilmesi. Gülhane Tıp Dergi 2011; 53: 264-270.

16. Çavdar S, Sümer EÇ, Eliaçık K, Arslan A, Koyun B, Korkmaz N, ve ark. İzmir'de liseye devam eden ergenlerin sağlık davranışları.Turk Pediatri Arsivi 2016; 51: 22-34.

17. Wang X, Ouyang Y, Liu J, Zhu M, Zhao G, Bao $\mathrm{W}$, et al. Fruit and vegetable consumption and mortality from all causes, cardiovascular disease, and cancer: systematic review and dose-response meta-analysis of prospective cohort studies. BMJ 2014; 349:4490.

18. Grimm KA, Kim SA, Yaroch AL, Scanlon KS. Fruit and vegetable intake during infancy and early childhood. Pediatrics 2014; 134(1): 63-69.

19. Erol S, Ergün A, Kadığlu H. Adölesanlarda meyve ve sebze tüketimi değişim süreci ölçeği türkçe forunun güvenilirlik ve geçerliliği. HSP 2016; 3(2):106-114.

20. Lynch C, Kristjansdottir AG, Te Velde SJ, Lien N, Roos E, Thorsdottir I, et al. Fruit and vegetable consumption in a sample of 11-yearold children in ten European countries-the PRO GREENS cross-sectional survey. Public Health Nutrition 2014; 17(11): 2436-2444.

21. Ball K, Crawford D, Mishra G. Socio-economic inequalities in women's fruit and vegetable intakes: a multilevel study of individual, social and environmental mediators. Public Health Nutrition 2006; 9: 623-630.

22. Attorp A, Scott JE, Yew AC, Rhodes RE, Barr SI, Naylor PJ. Associations between socioeconomic, parental and home environment factors and fruit and vegetable consumption of children in grades five and six in British Columbia, Canada. BMC Public Health 2014; 14(1): 150.

23. Peltzer K, Pengpid S. Fruits and vegetables consumption and associated factors among in- 
school adolescents in five Southeast Asian countries. International Journal of Environmental Research and Public Health 2012; 9(11): 3575-3587.

24. Wyse R, Campbell E, Nathan N, Wolfenden L. Associations between characteristics of the home food environment and fruit and vegetable intake in preschool children: a cross-sectional study. BMC Public Health 2011; 11(1): 938.

25. Terry-McElrath YM, O'Malley PM, Johnston LD. Accessibility over availability: associations between the school food environment and student fruit and green vegetable consumption. Childhood Obesity 2014; 10(3): 241-250. 
